\title{
Preparing Social Workers for Practice with LGBT Populations Affected by Substance Use: Perceptions from Students, Alumni and Service Providers
}

Michael P. Dentato PhD, MSW

Loyola University Chicago, mdentato@luc.edu

Brian Kelly

Loyola University Chicago, bkelly6@luc.edu

Michael R. Lloyd

Nikki Busch

Follow this and additional works at: https://ecommons.luc.edu/socialwork_facpubs

Part of the Feminist, Gender, and Sexuality Studies Commons, and the Social Work Commons

Author Manuscript

This is a pre-publication author manuscript of the final, published article.

\section{Recommended Citation}

Dentato, Michael P. PhD, MSW; Kelly, Brian; Lloyd, Michael R.; and Busch, Nikki. Preparing Social Workers for Practice with LGBT Populations Affected by Substance Use: Perceptions from Students, Alumni and Service Providers. Social Work Education, 37, 3: 294-314, 2017. Retrieved from Loyola eCommons, Social Work: School of Social Work Faculty Publications and Other Works, http://dx.doi.org/10.1080/ 02615479.2017.1406467

This Article is brought to you for free and open access by the Faculty Publications and Other Works by Department at Loyola eCommons. It has been accepted for inclusion in Social Work: School of Social Work Faculty Publications and Other Works by an authorized administrator of Loyola eCommons. For more information, please contact ecommons@luc.edu.

\section{(c) $($ () $\ominus$}

This work is licensed under a Creative Commons Attribution-Noncommercial-No Derivative Works 3.0 License.

(C) Taylor \& Francis 2017 
Social Work Education: The International Journal

Preparing social workers for the field of addictions and practice with those identifying as LGBT: Perceptions from students, alumni and service providers

To cite this article: Michael P. Dentato, Brian L. Kelly, Michael R. Lloyd \& Nikki Busch (2017): Preparing social workers for practice with LGBT populations affected by substance use: perceptions from students, alumni, and service providers, Social Work Education, DOI: $10.1080 / 02615479.2017 .1406467$

\begin{abstract}
Trends in the field of service among those with alcohol and other drug addictions highlight the urgent need for schools of social work to effectively train students to serve clients with substance use disorders, as well as to have cultural competence to effectively serve disproportionately affected and historically underserved lesbian, gay, bisexual, transgender (LGBT) consumers. Online surveys and interviews examined graduate social work (MSW)/certified alcohol and drug counselor (CADC) student preparedness to work in the field of addictions with members of the LGBT community within one university located within the United States. Overall, results indicated that students and alumni did not feel adequately prepared through coursework to practice with LGBT populations affected by substance use, while still feeling clinically competent to practice with LGB populations moreso than with transgender consumers. Similar findings related to unique differences associated with perceptions of faculty support, introducing LGBT topics and how they are handled in the classroom, along with field preparedness to practice with LGB individuals when compared to members of the transgender community. A majority of service providers noted an overall commitment and competence to serve LGBT consumers as well as positive perceptions of students and alumni to do the same. Implications will examine the critical role of faculty in addressing some of the challenges related to effective preparation of social work students to practice with LGBT consumers affected by substance use disorders, along with suggestions for changes within the curricula, and the need for ongoing field trainings and unique placement experiences.
\end{abstract}

Key words: LGBTQ, substance use, addiction disorders, student preparedness, service providers 


\section{Background}

Introduction. Alcohol and other drug abuse and dependence comprise varying addiction disorders that impact large numbers of individuals regardless of factors associated with socioeconomic status, race, gender, sexual orientation, and gender identity - and are often correlated with underlying mental health (e.g., dual diagnosis) disorders. Each year, approximately 67,500 participants partake in the National Survey on Drug Use and Health (NSDUH), which is conducted through the Substance Abuse and Mental Health Services Administration (SAMHSA) and examines the use of illicit drugs, alcohol and tobacco among the U.S. population, age 12 and over. Significant findings from 2015 NSDUH estimated that 20.8 million individuals age 12 and older ( $8.5 \%$ of that population overall) met the diagnostic criteria in the American Psychiatric Association's Diagnostic and Statistical Manual of Mental Disorders (DSM-5) for a substance use disorder, comprising approximately 7.7 million people with an illicit drug use disorder and an additional 15.7 million with alcohol use disorder (Center for Behavioral Health Statistics and Quality, 2016). Numbers are even more startling when examining use over the past 30 days in which 27.1 million people age 12 or older used an illicit drug, corresponding to approximately 1 in 10 Americans (10.1\%) (Center for Behavioral Health Statistics and Quality, 2016).

Impact upon the LGBT community. While substance use and addiction to alcohol and other drugs among lesbian, gay, bisexual, transgender (LGBT) populations remains understudied, researchers suggest that stress, coping, and minority stress factors (Meyer, Schwartz \& Frost, 2008; Meyer, 2003) likely contribute to substance use disorder rates among LGBT individuals 2-3 times that of the general U.S. population (Cochran et al., 2003; Cochran \& Cause, 2006; Institute of Medicine, 2011; McCabe, Bostwick, Hughes, West, \& Boyd, 
2010). McCabe, West, Hughes, et al., (2013) found that more than $60 \%$ of lesbian and bisexual women met the criteria for a lifetime DSM-IV substance use disorder compared with $24 \%$ of heterosexual women. McCabe et al., (2010) note that both male and female bisexuals had at least two times greater odds of family histories of alcohol or other drug problems than those who reported only opposite sex behaviors and relationships.

Openly LGBT clients entered treatment with greater frequency of substance use, a history of more mental health treatments, higher rates of homelessness, a greater likelihood of being victims of domestic violence, and more treatments for physical problems than heterosexual clients (Cochran \& Cause, 2006). Additionally, experiences of discrimination and the role of intersectionality must be considered. LGBT individuals may face discrimination based on race and ethnicity, socioeconomic status, as well as gender or sexual orientation and other related factors. Substance use disorders tended to be more prevalent among LGB respondents who reported any discrimination than among those who reported no discrimination (McCabe, et al., 2010).

It is important for providers to understand that substance use among the LGBT community may significantly be affected by factors such as age, affiliation with LGBT culture, level of stress, and how "out" an individual is, among others (Green \& Feinstein, 2012). Therefore, culturally sensitive, affirming, and accessible prevention and treatment programs are critical for addressing substance use among sexual minority communities. Cochran and Cauce (2006) note that social pressures and discrimination may limit the opportunities LGBT individuals have to socialize with one another. As a result, socializing among LGBT communities may be limited to bars and/or other places where substance use is often prevalent. Meyer's (2003) minority stress model demonstrates that discrimination, internalized 
homophobia, and social stigma can create a hostile and stressful environment for LGBT individuals, which contributes to mental health problems, including substance use disorders. Increasing our understanding of treatment outcomes for LGBT substance abusers is especially important since research has demonstrated that LGB clients enter treatment with more severe substance abuse problems than heterosexual clients (Cochran \& Cauce, 2006). Additionally, the stress in the lives of LGBT individuals, including an increased risk for domestic violence, as well as being more likely to have partners who drink or abuse substances, may increase substance use (Cochran \& Cauce, 2006).

LGBT treatment concerns. Ongoing healthcare reform predicts an additional 40-45 million individuals seeking treatment in the behavioral healthcare system, which presents an alarming concern and influx of patients for which the current workforce is not prepared (HRSA, 2016) and a growing crisis for the field of addictions (SAMHSA, 2014). According to the National Survey of Substance Abuse Treatment Services, only 5\% of substance use disorder treatment programs specialize in serving the LGBT community (SAMHSA, 2011). Senreich (2010) reports that LGBT members in group therapy are often the target of heterosexist comments from their fellow group members and workers may lack education about LGBT specific issues (e.g., social stigma and internalized homophobia). Thus, LGBT clients may not be open about their issues and may not feel supported by workers to do the "necessary therapeutic work to mitigate their substance use problems" (Senreich, 2010, p. 1077).

The predominant disease model within substance use treatment promotes a strong focus on treating the disease of alcoholism and addiction with relatively little focus on individual differences, particularly in early recovery (Flores, 2007). In the case of LGBT individuals, however, there is some evidence that acknowledging differences based on sexual minority status 
may improve a client's engagement in the treatment process (Cochran, Peavy, \& Robohm, 2007). LGBT substance users and clients fare better when agency settings, groups and programs are specifically tailored to address and affirm their unique needs. Additionally, some research has shown that LGBT individuals are more likely to attend treatment consistently if their counselors are also members of the same sexual minority groups (Cochran, Peavy, \& Robohm, 2007) or can provide some level of evidence of their ability to be LGBT affirming. Given the enormous amount of positive social changes occurring over the past ten years or so, it may be important from a historical context to note that a study conducted at one Pride Institute (an LGBTQ specific rehabilitation center in Minnesota) compared post-discharge abstinence rates of clients who were treated at that specialized setting with the abstinence rates of LGBT clients treated at four traditional rehabilitation locations. Results demonstrated that the LGBT clients who attended Pride Institute's programs had more favorable outcomes related to their abstinence over the long term (Ratner, Kosten, \& McLellan, 1991).

LGBT specific treatment programs appear to offer a supportive environment for recovery. However, Anderson (1996) notes that the use of separate programs for gay and bisexual clients may be unrealistic, as few cities have a large enough LGBT community to support such facilities. As an alternative, many traditional substance abuse programs have instituted specialized groups for LGBT clients within the framework of their existing programs. Cochran, Peavy, and Robohm (2007) found that such specialized LGBTQ programs may not be easy to locate, particularly outside of larger urban cities.

Preparedness for practice. There continues to be a need for social workers to assist those with substance use disorders, regardless of professional setting, yet most specifically within settings that predominantly serve those with addiction disorders. The Bureau of Labor 
Statistics projects the employment of social workers specializing in substance abuse to grow at a rate of 19\% during 2014-2024, much faster on average when compared to all other occupations (BLS, 2017). Social workers estimate that $18 \%$ of their clients across all practice areas have a substance use disorder, which is twice that of the general population (Weismiller, Whitaker, \& Smith, 2005). Yet, some studies report a lack of perceived preparedness and knowledge among recent graduates in the U.K. (Galvani \& Forrester, 2011) and the U.S. (Jani et al., 2009) to work with those impacted by substance abuse.

Several recent studies highlight the need for schools of social work in the U.S. (Fisher, McCleary, Dimock, \& Rohovit, 2014) and the U.K. (Galvani \& Allnock, 2014; Galvani, Dance, \& Hutchinson, 2013; Galvani \& Forrester, 2011) to better prepare and train students to serve clients with substance use disorders. These findings suggest social work education has historically neglected to incorporate substance use disorder content into curricula. According to a report surveying members of the U.S. National Association of Social Workers (NASW), only $42 \%$ of social work students have received any substance use disorder education, mostly via electives, rather than core courses in the curriculum (Weismiller et al., 2005). However, it is often recommended that schools of social work infuse substance use disorder material within the generalist curriculum, as well create substance abuse counselor training programs (Jani, 2009; Weismiller, et al., 2005; Wilkey, Lundgren, \& Amodeo, 2013).

Few studies have explored the inclusion of content on diverse populations, such as the LGBT community, in connection with substance use disorder education in social work curricula. Relatedly, one recent study of 1,018 BSW and MSW students within schools of social work in the United States and Canada found an overall lack of self-assessed readiness to practice with the LGBT community overall (Craig, Dentato, Messinger, \& McInroy, 2016). However, students in 
this study did report feeling more prepared to practice with LGBT populations when there was implicit program support for LGBTQ students, explicit inclusion of content in courses, and when such topics were handled well during classroom and field discussions alike (Craig, Dentato, et al., 2016).

Cochran, Peavy, \& Cauce (2007) found that substance use counselors in the field showed fewer homophobic beliefs than undergraduate students sampled in the 1998 study by Raja and Stokes (1998), yet there was still a "considerable range in the attitudes held by these counselors," (p. 201). While a range of attitudes (e.g., positive, negative, neutral) toward LGBT individuals may be expected within the general population, substance use counselors' attitudes are likely to have an impact upon the lives of the clients they treat across settings. In their study of substance abuse counselors, Cochran, Peavy, and Cauce (2007) found more positive attitudes toward LGBT individuals were held by gay and lesbian counselors, whereas heterosexual female counselors had less positive attitudes, and heterosexual male counselors had the most negative attitudes toward the LGBT population, as well as those that had few LGBT friends. In the same regard, over $25 \%$ of substance use counselors had seen or witnessed discrimination related to one's LGBT status within their agencies, and nearly $20 \%$ of counselors did not feel adequately trained to work with LGBT clients (Cochran, Peavy, \& Cauce, 2007).

Many organizations would benefit greatly from training and ongoing education related to understanding best practices for affirming LGBT focused care and treatment. Cochran, Peavy, and Robohm (2007) suggest that counselors approach LGBT substance users with an awareness of their multiple layers of oppression (e.g., substance use and sexual orientation certainly, but also other possible stigmas such as gender and race/ethnicity) and how these might impact their substance use. The authors further propose that an awareness of countertransference issues, 
particularly how these might reflect a counselor's discomfort or ambivalence regarding issues of sexual orientation or gender identity, is paramount to preserving the therapeutic relationship as an agent of client change. Finally, they recommend that counselors should work toward developing knowledge regarding LGBT-specific issues and express directly to their clients what they do not know (Cochran, Peavy, \& Robohm, 2007). This is reflected in several U.S. urban and rural areas, such as the City of Chicago, where a few agencies among scores of substance use treatment providers specifically specialize in LGBT substance use disorder care and treatment (IL Department of Human Services).

Field education. An analysis of U.S. National Association of Social Workers membership found that $53 \%$ of those surveyed had no training on substance abuse in the preceding year (Smith, Whitaker, \& Weismiller, 2006). Although 81\% of social workers reported having some substance abuse training during their lifetime, only $16 \%$ received training and education during their field placement. Galvani, Dance, and Hutchinson (2013) report similar findings from the U.K. In their theoretical work, Goodrich \& Luke (2011) argue that clinicians voice a similar lack of training around about sexual orientation and gender identity issues during their graduate and post-graduate training, as well as in their clinical supervision. This gap within training and supervision potentially works to underserve the LGBT population, as social workers and their supervisors may fail to acquire the knowledge, awareness, or skills necessary to intervene effectively. The lack of preparation could lead to ethical and legal breaches and unintentional harm when working with LGBTQ clients (Goodrich \& Luke, 2011). As the U.S. Council on Social Work Education (2015) refers to field work as the "signature pedagogy" of social work education (p.12), it is a remarkable finding that so few social workers learned about working with substance-abusing clients as part of their field education, especially because 
training on substance abuse can improve the knowledge, attitudes, and behaviors of clinicians who work with individuals with substance abuse problems (Straussner \& Vairo, 2007).

Based on this review of the literature, there is a need for LGBT-focused substance use disorder training amongst MSW students. The purpose of this study is to explore the perceptions of preparedness to work with LGBT substance misusing clients amongst a sample of students and alumni of a dual MSW and certified alcohol and other drug counseling training program. A team of researchers designed a survey and follow-up qualitative interview guide to address the following research questions: (1) What are student and alumni perceptions of LGBT-focused content within the program? (2) What are student and alumni perceptions of preparedness to work with LGBT individuals with substance use disorders? (3) What are the perceptions of student and alumni preparedness to work with LGBT individuals with substance use disorders from community service providers?

\section{Methods}

Upon receiving institutional review board approval from the primary author's institution, an internet-based survey was distributed to social work students currently enrolled in a certified alcohol and other drug abuse counselor (CADC) specialization within their MSW program, as well as alumni of the program, and addictions field/service providers to assess perceptions of student/alumni preparedness to work with LGBT populations in the addictions field within one large urban city located in the Midwest. The CADC program is an advanced state-accredited training program, where students complete three courses on substance-use disorder treatment and a substance use treatment field placement in conjunction with their MSW coursework.

The online survey was designed and distributed using Opinio, a web-based survey tool. An introductory email and survey link was distributed to current students and alumni through 
CADC program list serves. An introductory email and survey link was distributed to service providers through their work email addresses. Survey questions were developed through consultation amongst the research team, which include the current director of CADC program, the former interim director, and a faculty member, all of whom have teaching and practice experience with substance use and misuse among LGBT populations. Student and alumni survey questions explored perceptions of CADC coursework and related training to work with substance using and misusing LGBT individuals, perceptions of program faculty support and navigation of LGBT substance use disorder classroom content, and perceptions of field placements and preparedness to work with LGBT substance using and misusing populations. Service provider questions explored their perceptions of student and alumni preparedness to work with LGBT substance using and misusing individuals.

The online survey was conducted during the period of May 2014 through April 2016 with the potential to capture five CADC cohorts (e.g., 2012-2016) with average cohort size of twenty students. The survey was distributed to 100 students and alumni and 12 service providers. Alumni were no more than 3 years out of the program at the time of the survey. Inclusion criteria consisted of the following: (1) identification as a current MSW student, MSW alumni, or service provider in the field of addictions; (2) fluency in English; and (3) age 18 and older. Student, alumni, and service providers received 2 reminder emails to complete the survey throughout the study period. Following informed consent procedures, participants responded to a series of 40 questions (students/alumni) and 30 questions (service providers) related to their perceptions, generally completing the survey in a 30-minute time frame. Upon completion of the survey, participants were offered the option of providing their email address to be contacted for a followup qualitative interview. 
Nine participants indicated an interest in being contacted for follow-up qualitative interviews throughout the study period of May 2014 through April 2016. Of the 9 potential interviewees, 3 completed interviews during the period of September through December 2014. Consent procedures and interviews occurred in private spaces, either in the second author's office, which is located on a Midwestern urban university campus, or a private location identified by the interviewee. Interview questions focused on how respondents became interested in studying and/or working in the substance use field, their experiences in the CADC program and their exposure to LGBT content, and their readiness and interest to practice and work with LGBT substance-affected clients. Interviews lasted between 36 and 49 minutes and were audio recorded with the respondents' consent.

Analysis. Frequencies and cross-tabulations were computed using SPSS statistical software, allowing for a comparison of percentages. Descriptive analyses were used to examine student and alumni perceptions of competency and preparedness and to serve LGBT populations affected by substance use disorders; faculty support and classroom content; and assessment of field placement and preparedness; along with analyses of service provider's commitment and competence to provide substance use services for the LGBT community. Qualitative interview recordings were transcribed and then analyzed using a modified version of Emerson, Fretz, and Shaw's (1995) model of coding and memoing. Transcripts were read and treated as an entire data set, then openly coded while making initial memos. These codes and memos were then reviewed to identify themes that would support and add context to the quantitative findings. While quantitative findings provide some overview of participants' perceptions, qualitative findings offer more in-depth analysis of some of these results. 


\section{Findings}

Results from the online portion of this study indicate that the sample $(N=63)$ included currently enrolled students $(n=24)$; alumni $(n=34)$; and service providers $(n=5)$, with preliminary analysis demonstrating unique perceptions of preparedness to work with LGBT populations within the addictions community. Findings related to the qualitative follow-up interview component of this study indicate that the less diverse and smaller than anticipated sample $(N=3)$ included alumni who were between 1 and 3 years out of the program and identified as heterosexual male $(n=1)$, heterosexual female $(n=1)$, and queer female $(n=1)$. All interviewees identified as White, non-Hispanic. Initial findings will be presented related to student and alumni responses, followed by those of service providers.

\section{Student and Alumni Responses}

While the majority of survey respondents identified as heterosexual $(76 \%, n=44), 24 \%$ $(n=24)$ identified as gay, bisexual, queer, or questioning. Seventy-four percent of survey respondents identified as white and Non-Hispanic $(n=43), 69 \%$ identified as female $(n=40)$, and $53 \%$ were in their twenties $(n=31)$. Eighty-three percent of students and alumni also identified as LGBT allies $(n=48)$ and $62 \%(n=36)$ stated they were "very committed" to serving substance-affected LGBT consumers. Despite these predominant characteristics, only $62 \%$ of participants currently work in the field of substance use disorders $(n=36)$ and $59 \%$ of alumni had a current CADC $(n=20)$. Only $9 \%$ of students and alumni reported primarily working with LGBT consumers $(n=5)$ (Table 1$)$.

Self-assessment of preparedness and competency. When asked whether substance use disorder coursework assisted with preparing them for practice with LGB populations, students and alumni responded with "not very well" or "not well at all" $(n=22 ; 38 \%)$ when compared to 
"very well" or "somewhat well" $(n=16 ; 27 \%)$ or "neutral" $(n=17 ; 29 \%)$. When asked about working with transgender clients, students and alumni rated the impact of substance use disorder coursework as "not very well" or "not well at all" $(n=36 ; 62 \%)$ when compared to "neutral" $(n$ $=12 ; 20 \%)$ or "very well" or "somewhat well" $(n=8 ; 15 \%)$. Despite these findings, a majority of students and alumni felt "very competent" or "somewhat competent" in their clinical competency to serve lesbian $(n=31 ; 53 \%)$, gay $(n=37 ; 64 \%)$, and bisexual $(n=32 ; 55 \%)$ substance-affected consumers, when compared to those identifying as transgender $(n=26 ; 45 \%)$. Furthermore, the majority of students and alumni identified as "somewhat or very committed" ( $n$ $=45 ; 77 \%$ ) to work with LGBT substance-affected consumers (Table 2).

Qualitative interviews indicated similar sentiments regarding coursework and preparedness. The respondents who were all alumni, identified that components of the MSW program did not effectively prepare them to work with LGBT individuals. Such sentiments are reflected in the following comments:

I certainly don't think that anything in the program propelled me to be like, more culturally competent with this population.

I just don't recall ever really spending a lot of time talking about this specific population.

I don't recall having a class or even half of a class period spent talking about the substances of choice in the [LGBT] community.

All three qualitative interviewees represented above appeared to be in agreement that CADC coursework did not focus on the intersection of substance use and abuse with the LGBT community. These findings appear consistent with the results from the quantitative data regarding coursework preparedness.

Faculty support and navigating classroom content. Most students and alumni $(n=29$; $50 \%$ ) believed that between $76-100 \%$ of faculty teaching substance use disorder classes were 
supportive of LGB issues. Less than half of the students and alumni ( $n=25 ; 43 \%)$ believed that between $76-100 \%$ of faculty teaching substance use disorder classes were supportive of transgender issues. When asked to choose multiple categories, students and alumni identified that LGB issues were most often introduced in substance use disorder coursework through student led discussions $(n=36 ; 62 \%)$, required readings $(n=32 ; 55 \%)$, and as a faculty introduced topic $(n=17 ; 29 \%)$. Similarly, transgender issues were most often introduced in a similar way through student led discussions $(n=21 ; 35 \%)$, required readings $(n=18 ; 31 \%)$, and as a faculty introduced topic $(n=16 ; 27 \%)$ (Table 3$)$.

While the qualitative respondents did acknowledge some level of faculty support and leadership pertaining to introducing LGBT topics in CADC courses, one identified an important suggestion to enhance the explicit curricula:

I mean it's okay if an instructor doesn't have a real deep, deep knowledge of you know that particular issue in that community, but I think someone who either does counseling with them or, like I said, they can bring in a lot of guest speakers, would be something I think is important to me.

This comment may reflect the importance and significance of first-hand knowledge of how to work with LGBTQ individuals within substance abuse settings. This comment particularly seems less about instructors direct practice experience with diverse populations and more directly emphasizes the importance of utilizing primary sources of such knowledge to enhance student classroom experiences.

Overall students and alumni felt that LGB topics in substance disorder classes were handled "very well" or "somewhat well" $(n=16 ; 27 \%)$ when compared to "neutral" $(n=14$; $24 \%)$, or "not very well" or "not well at all" ( $n=14 ; 24 \%)$. Transgender topics followed an opposite distribution with most respondents noting that topics were handled "not very well" or "not well at all" $(n=23 ; 40 \%)$ when compared to "very well" or "somewhat well" $(n=13 ; 22 \%)$ 
and "neutral" ( $n=13 ; 22 \%)$. Interestingly, most students and alumni identified that readings and examples were "sometimes" $(n=18 ; 31 \%)$, "rarely" $(n=26 ; 45 \%)$ or "never" $(n=6 ; 10 \%)$ provided about LGB experiences, when compared to "sometimes" $(\mathrm{n}=10 ; 17 \%)$, "rarely" $(n=$ $22 ; 38 \%)$, or "never" $(n=19 ; 33 \%)$ provided about transgender experiences. This affirms earlier findings related to distinct differences between how LGB and T topics are navigated within the curricula and classroom experiences. One respondent notably underscored the need for a strengths-based perspective when addressing LGBT substance use and addiction issues in class:

I feel like it's really important to provide treatment that takes into account the strengths and challenges of particular communities and you know, stigma that may come up too in other settings.

Lastly, students responded that the role and/or challenges of being a LGBT social worker were "sometimes" $(n=21 ; 36 \%)$, "rarely" $(n=18 ; 31 \%)$, or "never" $(n=12 ; 21 \%)$ discussed in their substance use disorder courses, underscoring a clear need to be more inclusive of examining diverse student needs and readiness for practice (Table 3).

Assessment of field placements and preparedness. Students and alumni noted that their substance abuse field placements prepared them "very well" or "somewhat well" ( $n=17 ; 29 \%)$, "neutral" ( $n=15 ; 26 \%)$, or "not very well" or "not well at all" $(n=24 ; 41 \%)$ to effectively serve LGB consumers. Similar to previous findings in the data, students felt less prepared to effectively serve transgender clients with most rating "not very well" or "not well at all" $(n=34$; $59 \%)$ when compared to "very well" or "somewhat well" $(n=10 ; 7 \%)$ and "neutral" $(n=11$; $19 \%$ ) levels of competence. Despite this, the majority of students and alumni rated having specialized clinical competence to work with substance-affected LGBT consumers as "very important" or "somewhat important" $(n=43 ; 74 \%)$ (Table 4). 
The interviewees also reflected a similar range of preparedness. While some felt they were prepared, others did not. This most often reflected both the resources of the actual agency setting and field site as well as the resources brought by the individual:

I think at my CADC placement [,] I think we did ask them a few things around it, but [...] there was no discussion on how to make those conversations comfortable.

My second placement was very helpful in terms of working in the LGBT community because the people who ran the practice were gay men [...] one of the best trainings I got was about how stigma impacts identity and development.

Even my internship did not prepare me at all to work with the LGBT community. Were there possibly gay men during my 700-plus hours? Oh, statistically, I would say yes. Did I know if they were? No idea. Was it ever brought up in any kind of group therapy session or individual or anything like that? Not at all.

While there was some dissonance reported surrounding field placement resources, the

interviewees all agreed that they had a willingness to work with this population as noted below:

Definitely [...] it wouldn't matter if you were lesbian, gay, I wouldn't be uncomfortable with a client like that, in fact I would hope and think that because of my personality and kind of the person I am that clients would feel comfortable around me.

I think even when you're working with people with substance abuse issues they have so many other issues, so you're like oh, if I just do substance use I close the door on traumano, I close the door on family relationships-no, like, I close the door on LGBT issues-no, it's just, like, again, substance use is just an overlay of all the other stuff that's going on in peoples' lives... I would like to get more experience, I consider this [working with LGBT substance-affected clients] to be a long-term commitment, I mean I think that it's something that I'll always be interested in doing.

I would say, I mean, I don't know, my dream job might actually be working at an LGBTQ-specific substance abuse treatment program, so I would say probably, I have a pretty strong commitment.

\section{Service Provider Responses}

As part of this study, substance abuse service providers $(N=5)$ were also surveyed to learn more about how LGBT clients are being served within substance abuse treatment settings (Table 5). Agency respondents from all four American Society of Addiction Medicine (ASAM) 
levels of care responded to questions about their services with $60 \%$ identifying as LGBT affirming $(n=3)$. ASAM's treatment criteria assists providers with creating comprehensive and individualized treatment plans for adolescents and adults through a multidimensional patient assessment across five levels of treatment based on the degree of direct medical management provided, the structure, safety and security provided and the intensity of treatment services provided (See: https://www.asam.org/resources/the-asam-criteria/about).

When asked about the percentage of lesbian, gay, bisexual or transgender clients, agency respondents noted at least $25 \%$ of their clients identified as LGBT, with one of those respondents noting that up to $75 \%$ of their clients identified as gay. Regarding the racial/ethnic composition of clients, agency respondents reported most frequently serving Caucasian clients, followed by African Americans, Hispanics/Latinos, and Asians, Native Americans and those identifying as multi-racial. Agency respondents reported serving more male-identified clients than female, with trans male and trans female clients comprising up to $25 \%$ of their overall client population.

Commitment, competence, and services. Agency respondents reported their commitment to serve LGBT clients in similar ways (Table 6). Four agency respondents (80\%) reported that they were "very committed" to serving LGBT consumers. Three agency respondents $(60 \%)$ noted that they were "very competent" in terms of serving substance-affected lesbian, gay, bisexual, and transgender consumers, with one agency respondent noting "not competent" with regard to serving transgender consumers. Sixty percent of agency respondents $(n=3)$ noted that it was "very important" that staff and interns have specialized clinical training to serve substance-affected LGBT consumers at their agency. Specifically, $40 \%$ of agency respondents $(n=2)$ noted that the social work coursework and field placements prepared student interns and alumni "very well" to effectively serve LGB consumers. Another $40 \%$ of agency 
respondents $(n=2)$ reported social work coursework and field placements prepared student interns and alumni "somewhat well” to effectively serve LGB consumers. Forty percent of agency respondents $(n=2)$ noted that the social work coursework and field placements prepared student interns and alumni "very well" to effectively serve transgender consumers. Another agency respondent reported social work coursework and field placements prepared student interns and alumni "somewhat well" to effectively serve transgender consumers. Overall, 40\% of agency respondents $(n=2)$ reported students and alumni as "very competent" when working with LGBT consumers.

\section{Discussion}

The curricula. Findings from this study demonstrate that the majority of social work students and alumni identify as LGBT allies and are committed to working with LGBT substance-affected consumers, but at best they rate themselves as only somewhat ready and prepared to work with these populations. Similar to responses in studies reporting the lack of substance use disorder content in social work curricula in the U.S. (Fisher, McCleary, Dimock, \& Rohovit, 2014) and the U.K. (Galvani \& Allnock, 2014; Galvani, Dance, \& Hutchinson, 2013; Galvani \& Forrester, 2011), these responses suggest that MSW and CADC curricula are lacking in content and training on how to work with LGBT substance-affected consumers. This is problematic considering the higher than average rates of substance use disorders that disproportionately impact LGBT communities (Cochran et al., 2003; Cochran \& Cause, 2006; Institute of Medicine, 2011; McCabe et al., 2010), as well as the increased risk for suicide among LGBT populations (Haas et al., 2010). Further, if students and alumni are identifying as allies who are committed to working with LGBT substance-affected populations, it is important to develop and implement MSW and CADC curricula that address the need for LGBT specific 
services and satisfies student and alumni desire to provide such services. As Teater (2014) notes in her commentary on the integration of substance use disorder knowledge in social work education, this content should be threaded throughout curricula and informed by empirical and practical knowledge.

Unique training opportunities. While these findings suggest there are considerable gaps across the curriculum, government sponsored training programs, such as those promoting use of the SBIRT model (Screening, Brief Intervention and Referral to Treatment), may offer opportunities to build foundation and advanced content on concise substance abuse treatment and prevention education that focuses on the intersections of addiction, minority status, and related factors. Such training programs have been found to be successful across the U.S. (Gotham et al., 2015; Puskar et al., 2016) providing interprofessional experiences across disciplines, diverse settings, as well as providing strong evidence for the linkage between education and social work practice (Russett, 2015). For more information on the SBIRT model, please see http://www.integration.samhsa.gov/clinical-practice/sbirt

Role of faculty. Study findings also demonstrate that students and alumni experience faculty as generally supportive of LGBT issues across CADC courses. However, they also report that classroom discussions of LGBT issues are primarily driven by students and required readings, and are less often introduced by faculty. While faculty may require LGBT course readings, it appears that participants in this study felt they often took the lead in engaging in related discussions. This may be due to some faculty feeling less comfortable exploring such topics when teaching from standardized syllabi used across multiple sections. This, and the decrease in the numbers across the response categories "student led discussions," "required readings," and "faculty introduced topic" when comparing LGB and T populations and topics in 
CADC courses suggests a need for increased faculty exposure and training in LGBT related issues and the impact of substance use disorders upon LGBT populations. Relatedly, the findings of this study underscore a unique gap specifically related to comfort, preparedness, and perceptions of competence associated with practice among the transgender community affected by substance use disorders when compared to lesbian, gay and bisexual individuals. Therefore, it may be helpful for faculty, students, alumni and field educators alike to engage in a necessary discourse related to the expansion of knowledge and affirming practice skills specifically related to practice with members of the transgender community.

While it is important and laudable for students to step up and assist in shaping and driving classroom discussions, it is important for educators to model inclusivity and just practice in developing and delivering course content, and in leading discussions on serving sexual minority and gender non-conforming populations. One simple way instructors and faculty may model leadership in discussing gender identity in MSW and CADC courses is through including gender and name statements in syllabi, as well as use of gender pronouns in classroom introductions (e.g., "Hello, my name is Sam and I use they pronouns.”) (Kelly \& Ratliff, 2017). Doing so may create an environment of inclusivity, which may in turn allow for instructor and faculty driven conversations on LGBT related issues.

Field placement experiences. Findings from a research report examining educational experiences of LGBTQ students in North American schools of social work $(n=1,018)$ by Craig, McInroy, Dentato, Austin and Messinger (2015) found that a notable number of respondents sometimes or often experienced conflict during their field practicums regarding their own sexual orientation or gender identity. Relatedly, guidelines for affirmative social work education published by Austin et al. (2016) and Craig, Alessi, et al., (2016) noted specific suggestions for 
field experiences including assessing for agency non-discrimination policies, offering LGBTQ affirmative trainings for all staff members, as well as through assessing field curricula on an ongoing basis to insure competence, inclusion and representation, creating a list of LGBTQ agency based mentors and experts in the field, among other pertinent and relevant suggestions. In the current study, students and alumni reported feeling even less prepared to work with transgender substance-affected consumers, suggesting the need for additional and specific field placement trainings on how to engage and work with transgender populations. Overall, the majority of students and alumni did not perceive their coursework and field placement experiences to effectively prepare them to work with LGBT substance using consumers, which may suggest that the lack of such curricula and field placement content, exposure, and training is having an impact on their capacity to confidently and effectively serve this population.

While the small sample of agencies and service providers surveyed appear committed and willing to serve LGBT populations, there remains a lack of services for LGBT substanceaffected consumers. In a climate of increasing austerity for mental health and substance use services, and a shift in the political pendulum toward conservative values, it is imperative to continue to advocate for services for the vulnerable and oppressed in society. In addition, it is equally imperative to train an effective workforce to serve the vulnerable and oppressed, which includes LGBT substance-affected consumers.

Limitations. There are several limitations to this study that include the demographic composition, sample size, methods, and representation of findings. This study examined several small cohorts of students and alumni within one social work program, as well as a limited number of field providers located within a large urban setting. The demographic composition of study participants, while similar to other social work programs across the U.S. with regard to the 
prominence of cisgender, heterosexual, White Non-Hispanic students, does not offer the perceptions of racial and ethnically diverse student populations. In the same regard, this study may not emphasize the unique challenges faced by other schools located within rural or NonWestern social work programs. The number of qualitative student and alumni respondents was quite low due to a lack of response and small cohort size of the CADC program located within one university, ultimately impacting the robustness of study results. The use of technology for the online portion of the study may have increased the likelihood of potential respondents ignoring emails related to participation, while it also may have impacted response bias, careless responses, lack of a controlled setting, or resulted in other technical challenges. Additional study limitations pertain to the inability of the investigators ability to fully insure reliable responses, as well as the potential for participant's responding due to a willingness to please. Even with such limitations to the study, the examination of student, alumni and field provider perceptions of preparedness to practice in the field of addictions with the LGBT community does provide some insight into the limited literature and research in these areas.

\section{Conclusion}

The effective preparation of social workers for affirming practice with members of the LGBT community impacted by substance use disorders across diverse settings remains essential. Relatedly, the implications of assessing the role of sexual orientation and gender identity in terms of substance use and abuse is a critical task for social work students as well as postgraduate professionals in the field. As one of the interviewees of this study so eloquently noted: “...substance use is just an overlay of all the other stuff that's going on in peoples' lives." Indeed, while the components of a substance user or abuser's life may vary widely, there are certain factors that may place an individual at an elevated risk for use or addiction. 
As illustrated through this mixed methods study, social work students and recent graduates often lack the knowledge and resources about how to best serve sexual and gender minority populations. There are also considerable gaps across the curriculum, as well as necessary resources for social work practitioners working within the field of addictions. This study underscores the need for more comprehensive substance abuse treatment and prevention education - one that must focus on the intersection of lived experiences and diverse identities. Progress must continue in the field of social work education related to effective teaching and preparation of students on the intersectionality of addiction (e.g., prevention, education and treatment) and all minority populations.

Social work students studying to become certified in addictions, as well as graduates of such certification programs, should be effectively prepared to work with the entire community, especially subsets of minority populations with greater prevalence or risk for alcohol and other drug abuse disorders such as the transgender and gender non-conforming community. Ultimately, administrators and faculty within MSW programs should continually evaluate foundation and advanced curricula to ensure explicit infusion of substance use disorder content to positively impact student preparedness to work among all minority populations, including the LGBTQ community, during coursework or field practicum; as well as to ensure ongoing communication with substance use service providers to ensure MSW programs are best meeting the long term needs of such organizations, the diverse communities being served; while assessing the need for continued post-graduate training opportunities. 


\section{References}

Anderson, S. (1996). Substance abuse and dependency in gay men and lesbians. Journal of Gay and Lesbian Social Services, 5, 1, 59-76.

Bureau of Labor Statistics, U.S. Department of Labor, Occupational Outlook Handbook, 201617 Edition, Social Workers. Retrieved from: https://www.bls.gov/ooh/community-andsocial-service/social-workers.htm on September 24, 2017.

Center for Behavioral Health Statistics and Quality. (2016). Key substance use and mental health indicators in the United States: Results from the 2015 National Survey on Drug Use and Health (HHS Publication No. SMA 16-4984, NSDUH Series H-51). Retrieved from http://www.samhsa.gov/data/

Cochran, B. N., \& Cauce, A. M. (2006). Characteristics of lesbian, gay, bisexual, and transgender individuals entering substance abuse treatment. Journal of Substance Abuse Treatment, 30, 2, 135-146.

Cochran, B., Peavy, K., \& Cauce, A. (2007). Substance abuse treatment providers' explicit and implicit attitudes regarding sexual minorities. Journal of Homosexuality, 53, 3, 181-207.

Cochran, B., Peavy, K., \& Robohm, J. (2007). Do specialized services exist for LGBTQ individuals seeking treatment for substance misuse? A study of available treatment programs. Substance Use \& Misuse, 42, 1, 161-176.

Council on Social Work Education. (2015). Educational policy and accreditation standards. Retrieved at: http://www.cswe.org/File.aspx?id=94704.

Craig, S. L., McInroy, L. B., Dentato, M. P., Austin, A., \& Messinger, L. (2015). Social work students speak out! The experiences of lesbian, gay, bisexual, transgender and queer 
students in social work programs: A study report from the CSWE Council on Sexual Orientation and Gender Identity and Expression (pp. 1-19). Toronto: Authors.

Craig, S. L., Alessi, E. J., Fisher-Borne, M., Dentato, M. P., Austin, A., Paceley, M., ... Van Der Horn, R. (2016). Guidelines for affirmative social work education: Enhancing the climate for LGBQQ students, staff, and faculty in social work education (pp. 1-17). Alexandria, VA: Council on Social Work Education.

Craig, S. L., Dentato, M. P., Messinger, L., \& McInroy, L. (2016). Educational determinants of readiness to practice with LGBTQ clients: Social work students speak out. British Journal of Social Work, 46(1), 115-134. doi:10.1093/bjsw/bcu107

Dentato, M. P., Craig, S. L., Messinger, L., Lloyd, M. R., \& McInroy, L. B. (2014). Outness among LGBTQ social work students in North America: The contribution of environmental supports and perceptions of comfort. Social Work Education, 33(4), 485501. doi:10.1080/02615479.2013.855193

Dentato, M. P., Craig, S. L., Lloyd, M. R., Kelly, B. L., Wright, C., \& Austin, A. (2016). Homophobia within schools of social work: The critical need for affirming classroom settings and effective preparation for service with the LGBTQ community. Social Work Education, 35(6), 672-692. doi:10.1080/02615479.2016.1150452

Emerson, R., Fretz, R., \& Shaw, L. (1995). Writing ethnographic fieldnotes. Chicago, IL: The University of Chicago Press.

Fisher, C. M., McCleary, J. S., Dimock, P., \& Rohovit, J. (2014). Provider preparedness for treatment of co-occurring disorders: Comparison of social workers and alcohol and drug counselors. Social Work Education, 33(5), 626-641.

Flores, P. J. (2007). Group psychotherapy with addicted populations: An integration of twelve- 
step and psychodynamic theory. 3rd. ed. Binghamton, NY: The Haworth Press.

Galvani, S., \& Allnock, D. (2014). The nature and extent of substance use education in qualifying social work programmes in England. Social Work Education, 33(5), 573-588.

Galvani, S., Dance, C., \& Hutchinson, A. (2013). Substance use training experiences and needs: findings from a national survey of social care professionals in England. Social Work Education, 32(7), 888-905.

Galvani, S., \& Forrester, D. (2011). How well prepared are newly qualified social workers for working with substance use issues? Findings from a national survey in England. Social Work Education, 30(04), 422-439.

Goodrich, K., \& Luke, M. (2011). The LGBTQ responsive model for supervision of group work. The Journal for Specialists in Group Work, 36, 1, 22-40.

Gotham, H., Knopf-Amelung, S., Haggins, I., Lynn, J., Young, P., Manney, R., \& Kohnle, K. (2015). Interprofessional approaches to integrating SBIRT into students' clinical experiences. Addiction Science and Clinical Practice, 10(Suppl. 2), O21.

Green, K. \& Feinstein, B. (2012). Substance use in lesbian, gay, and bisexual populations: an update on empirical research and implications for treatment. Psychology of Addictive Behaviors, 26(2), 265-278.

Haas, A., Eliason, M., Mays, V., Mathy, R., Cochran, S., D'Augelli, A., . . Clayton, P. (2010). Suicide and suicide risk in lesbian, gay, bisexual, and transgender populations: Review and recommendations. Journal of Homosexuality, 58(1), 10-51.

Health Resources and Services Administration (HRSA)/National Center for Health Workforce 
Analysis; Substance Abuse and Mental Health Services Administration/Office of Policy, Planning, and Innovation. (November 2016). National Projections of Supply and Demand for Behavioral Health Practitioners: 2013-2025. Rockville, Maryland.

Illinois Department of Human Services (2005). Safety and sobriety manual: Best practices in domestic violence and substance abuse. Retrieved on September 24, 2017 at: http://www.dhs.state.il.us/page.aspx?item=38468

Institute of Medicine (U.S.). (2011). The health of lesbian, gay, bisexual, and transgender people: Building a foundation for better understanding. Washington, DC: National Academies Press.

Jani, J. S. Sowbel, L. Smith-Osborne, A. Yum, J. Mollette, A. Hall, D. \& Bina, R. (2009). Perceived preparedness and knowledge of substance abuse among recent MSW graduates: Advanced standing revisited. Journal of Social Work Practice in the Addictions, 9, 4, 381-399.

Kelly, B. L., \& Ratliff, G. A. (2017). Strengths-affirming practice with LGBTQ youth. In M. P. Dentato (Ed.), Social work practice with the LGBTQ community: The intersection of history, health, mental health and policy factors (pp. 137-158). New York, NY: Oxford University Press.

McCabe, S., Bostwick, W., Hughes, T., West, B., \& Boyd, C. (2010). The relationship between discrimination and substance use disorders among lesbian, gay, and bisexual adults in the United States. American Journal of Public Health, 100(10), 1946-1952.

doi:10.2105/AJPH.2009.163147 
McCabe, S. E., West, B. T., Hughes, T. L., \& Boyd, C. J. (2013). Sexual orientation and substance abuse treatment utilization in the United States: Results from a national survey. Journal of substance abuse treatment, 44(1), 4-12.

Meyer, I. H. (2003). Prejudice, social stress, and mental health in lesbian, gay and bisexual populations: Conceptual issues and research evidence. Psychological Bulletin, 129, 674697.

Meyer, I. H., Schwartz, S. \& Frost, D. M. (2008). Social patterning of stress and coping: Does disadvantaged social statuses confer more stress and fewer coping resources? Social Science \& Medicine, 67, 368-379.

Puskar, K., Kane, I., Lee, H., Mitchell, A. M., Albrecht, S., Frank, L., Hagle, H., Lindsay, D., \& Houze, M.P. (2016). Interprofessional screening, brief intervention, and referral to treatment (SBIRT) education for registered nurses and behavioral health professionals. Issues in Mental Health Nursing, 37(9), 682-687.

Raja, S. \& Stokes, J. P. (1998). Assessing attitudes toward lesbians and gay men: The modern homophobia scale. Journal of Gay, Lesbian, and Bisexual Identity, 3, 113-134.

Russett, J. (2015). Changing systems: Integrating screening, brief intervention and referral to treatment (SBIRT) in social work practice. Field Educator, 5(2), 1-5.

Senreich, E. (2010). Are specialized LGBT program components helpful for gay and bisexual men in substance abuse treatment? Substance Use \& Misuse, 45, 7-8.

Substance Abuse and Mental Health Services Administration, (SAMHSA). (2011). Data on substance abuse treatment facilities. BHSIS Series S-64, HHS Publication No. (SMA) 124730. Rockville, MD. 
Substance Abuse and Mental Health Services Administration, (SAMHSA). 2014. Results from the 2013 National Survey on Drug Use and Health: Summary of National Findings, NSDUH Series H-48, HHS Publication No. (SMA) 14-4863. Rockville, MD.

Teater, B. (2014). Whose responsibility is it? A call for the integration of the knowledge of substance misuse in social work education, practice and research. Social Work Education, 33(5), 619-625.

Weismiller, T., Whitaker, T. \& Smith, M. (2005). National Association of Social Workers Practice Research Network III: Final Report. Retrieved from http://www.socialworkers.org/naswprn/surveyThree/report0205.pdf on February 10, 2017.

Wilkey, C., Lundgren, L., Amodeo, M. (2013). Addiction training in social work schools: a nationwide analysis. Journal of Social Work Practice in the Addictions, 13, 192-210. 
Table 1: Participant Characteristics $(N=58)$

\begin{tabular}{|c|c|c|}
\hline Characteristic $^{1}$ & $n$ & $\%$ \\
\hline Student & 24 & 41.4 \\
\hline Alumni & 34 & 58.6 \\
\hline \multicolumn{3}{|l|}{ Gender $(n=53)$} \\
\hline Male & 12 & 20.7 \\
\hline Female & 40 & 69.0 \\
\hline Transmale & 1 & 1.7 \\
\hline \multicolumn{3}{|l|}{ Age $(n=53)$} \\
\hline $20-29$ & 31 & 53.4 \\
\hline $30-39$ & 13 & 22.4 \\
\hline $40-49$ & 2 & 3.4 \\
\hline $50-59$ & 6 & 10.3 \\
\hline $60-69$ & 1 & 1.7 \\
\hline \multicolumn{3}{|l|}{ Race $(n=52)$} \\
\hline Black, Hispanic & 2 & 3.4 \\
\hline Black, Non-Hispanic & 2 & 3.4 \\
\hline White, Hispanic & 4 & 6.9 \\
\hline White, Non-Hispanic & 43 & 74.1 \\
\hline Multi-Racial & 1 & 1.7 \\
\hline \multicolumn{3}{|l|}{ Sexual Orientation $(n=53)$} \\
\hline Gay & 5 & 8.6 \\
\hline Bisexual & 2 & 3.4 \\
\hline Queer & 1 & 1.7 \\
\hline Questioning & 1 & 1.7 \\
\hline Heterosexual & 44 & 75.8 \\
\hline \multicolumn{3}{|c|}{ Identify as LGBT Ally $(n=53)$} \\
\hline Yes & 48 & 82.7 \\
\hline No & 5 & 8.6 \\
\hline \multicolumn{3}{|c|}{ Certified AOD Counselor $(n=53)$} \\
\hline Yes & 20 & 34.5 \\
\hline No & 33 & 56.9 \\
\hline \multicolumn{3}{|c|}{ Current Practice in SUD $(n=53)$} \\
\hline Yes & 36 & 62.1 \\
\hline No & 17 & 29.3 \\
\hline \multicolumn{3}{|c|}{$\begin{array}{l}\text { Current Practice } \mathrm{w} / \mathrm{LGBT} \text { Consumers } \\
(n=53)\end{array}$} \\
\hline Yes & 8 & 13.8 \\
\hline No & 45 & 77.6 \\
\hline
\end{tabular}

${ }^{1}$ Individual percentages calculated using all potential respondents $(N=58)$ 
Table 2: Self-Assessment: Coursework Preparedness, Clinical Competency \& Commitment by LGBT Consumer $(N=58)$

\begin{tabular}{|c|c|c|c|c|c|}
\hline $\begin{array}{l}\text { Coursework } \\
\text { Preparedness }{ }^{1} \\
(n=56)\end{array}$ & $\begin{array}{l}\text { Very Well } \\
n(\%)\end{array}$ & $\begin{array}{l}\text { Somewhat Well } \\
n(\%)\end{array}$ & $\begin{array}{l}\text { Neutral } \\
n(\%)\end{array}$ & $\begin{array}{l}\text { Not Very Well } \\
n(\%)\end{array}$ & $\begin{array}{l}\text { Not Well at All } \\
n(\%)\end{array}$ \\
\hline LGB & $2(3.4)$ & $14(24.1)$ & $17(29.3)$ & $16(27.6)$ & $6(10.3)$ \\
\hline Transgender & $2(3.4)$ & $6(10.3)$ & $12(20.7)$ & $17(29.3)$ & $18(31.0)$ \\
\hline $\begin{array}{l}\text { Clinical } \\
\text { Competence }^{1} \\
(n=55)\end{array}$ & $\begin{array}{l}\text { Very } \\
\text { Competent } \\
n(\%)\end{array}$ & $\begin{array}{l}\text { Somewhat } \\
\text { Competent } \\
n(\%)\end{array}$ & $\begin{array}{l}\text { Neutral } \\
n(\%)\end{array}$ & $\begin{array}{l}\text { Not Very } \\
\text { Competent } \\
n(\%)\end{array}$ & $\begin{array}{l}\text { Not Competent } \\
\text { at All } \\
n(\%)\end{array}$ \\
\hline Lesbian & $9(1.5)$ & $22(38.0)$ & $11(18.9)$ & $10(17.2)$ & $2(3.4)$ \\
\hline Gay & $11(18.9)$ & $26(44.8)$ & $6(10.3)$ & $8(13.8)$ & $3(5.2)$ \\
\hline Bisexual & $8(13.8)$ & $24(41.4)$ & $11(18.9)$ & $7(12.1)$ & $5(8.6)$ \\
\hline Transgender & $6(10.3)$ & $20(34.5)$ & $9(15.5)$ & $11(18.9)$ & $8(13.8)$ \\
\hline $\begin{array}{l}\text { Commitment to } \\
\text { Serve }^{1} \\
(n=55)\end{array}$ & $\begin{array}{l}\text { Very } \\
\text { Committed } \\
n(\%)\end{array}$ & $\begin{array}{l}\text { Somewhat } \\
\text { Committed } \\
n(\%)\end{array}$ & $\begin{array}{l}\text { Neutral } \\
n(\%)\end{array}$ & $\begin{array}{l}\text { Not Committed } \\
n(\%)\end{array}$ & $\begin{array}{l}\text { Do Not Know } \\
n(\%)\end{array}$ \\
\hline LGBT & $36(62.0)$ & $9(15.5)$ & $5(8.6)$ & $4(6.9)$ & $1(1.7)$ \\
\hline
\end{tabular}

${ }^{1}$ Individual percentages calculated using all potential respondents $(N=58)$ 
Table 3: Faculty Support \& Classroom Content by LGBT Topics $(N=58)$

\begin{tabular}{|c|c|c|c|c|c|}
\hline $\begin{array}{l}\text { Faculty Support }{ }^{1} \\
(n=54)\end{array}$ & $\begin{array}{l}0-25 \% \\
n(\%)\end{array}$ & $\begin{array}{l}26-50 \% \\
n(\%)\end{array}$ & $\begin{array}{l}51-75 \% \\
n(\%)\end{array}$ & $\begin{array}{l}76-100 \% \\
n(\%)\end{array}$ & $\begin{array}{l}\text { Do Not Know } \\
n(\%)\end{array}$ \\
\hline LGB & $4(6.9)$ & $5(8.6)$ & $8(13.8)$ & $29(50.0)$ & $8(13.8)$ \\
\hline Transgender & $7(12.1)$ & $3(5.2)$ & $8(13.8)$ & $25(43.1)$ & $11(18.9)$ \\
\hline $\begin{array}{l}\text { LGBT Topics } \\
\text { (Introduced) }\end{array}$ & $\begin{array}{l}\text { Student Led } \\
\text { Discussion } \\
n(\%)\end{array}$ & $\begin{array}{l}\text { Faculty } \\
\text { Introduced Topic } \\
n(\%)\end{array}$ & $\begin{array}{l}\text { Required } \\
\text { Readings } \\
n(\%)\end{array}$ & $\begin{array}{l}\text { Optional } \\
\text { Readings and } \\
\text { Research } \\
n(\%)\end{array}$ & $\begin{array}{l}\text { Guest Speakers, } \\
\text { Films, Videos } \\
n(\%)\end{array}$ \\
\hline LGB $(n=50)$ & $36(62.0)$ & $29(50.0)$ & $32(55.2)$ & $28(48.3)$ & $17(29.3)$ \\
\hline $\begin{array}{l}\text { Transgender } \\
(n=37)\end{array}$ & $21(36.2)$ & $16(27.6)$ & $18(31.0)$ & $21(36.2)$ & $9(15.5)$ \\
\hline $\begin{array}{l}\text { LGBT Topics }^{1} \\
\text { (Handled) } \\
(n=51)\end{array}$ & $\begin{array}{l}\text { Very Well } \\
n(\%)\end{array}$ & $\begin{array}{l}\text { Somewhat Well } \\
n(\%)\end{array}$ & $\begin{array}{l}\text { Neutral } \\
n(\%)\end{array}$ & $\begin{array}{l}\text { Not Very Well } \\
n(\%)\end{array}$ & $\begin{array}{l}\text { Not Well at All } \\
n(\%)\end{array}$ \\
\hline LGB & $3(5.2)$ & $13(22.4)$ & $14(24.1)$ & $14(21.1)$ & $5(8.6)$ \\
\hline Transgender & $2(3.4)$ & $11(18.9)$ & $13(22.4)$ & $12(20.7)$ & $11(18.9)$ \\
\hline $\begin{array}{l}\text { LGBT Topics }^{1} \\
\text { (Frequency) } \\
(n=51)\end{array}$ & $\begin{array}{l}\text { Sometimes } \\
n(\%)\end{array}$ & $\begin{array}{l}\text { Rarely } \\
n(\%)\end{array}$ & $\begin{array}{l}\text { Never } \\
n(\%)\end{array}$ & & \\
\hline LGB & $19(32.7)$ & $26(44.8)$ & $6(10.3)$ & & \\
\hline Transgender & $10(17.2)$ & $22(37.9)$ & $19(32.7)$ & & \\
\hline \multirow{2}{*}{$\begin{array}{l}\text { Role of being an } \\
\text { LGBT SW }^{1} \\
\text { (Frequency) } \\
(n=51)\end{array}$} & $\begin{array}{l}\text { Sometimes } \\
n(\%)\end{array}$ & $\begin{array}{l}\text { Rarely } \\
n(\%)\end{array}$ & $\begin{array}{l}\text { Never } \\
n(\%)\end{array}$ & & \\
\hline & $21(36.2)$ & $18(31.0)$ & $12(20.6)$ & & \\
\hline
\end{tabular}

${ }^{1}$ Individual percentages calculated using all potential respondents $(N=58)$ 
Table 4: Assessment of Field Placements, Specialized Clinical Competence and Preparedness by LGBT Consumer $(N=58)$

\begin{tabular}{|c|c|c|c|c|c|}
\hline $\begin{array}{l}\text { Field Placement }^{1} \\
\text { (Preparedness) } \\
(n=56)\end{array}$ & $\begin{array}{l}\text { Very Well } \\
n(\%)\end{array}$ & $\begin{array}{l}\text { Somewhat Well } \\
n(\%)\end{array}$ & $\begin{array}{l}\text { Neutral } \\
n(\%)\end{array}$ & $\begin{array}{l}\text { Not Very Well } \\
n(\%)\end{array}$ & $\begin{array}{l}\text { Not Well at All } \\
n(\%)\end{array}$ \\
\hline LGB & $4(6.9)$ & $13(22.4)$ & $15(25.9)$ & $16(27.6)$ & $8(13.8)$ \\
\hline Transgender & $3(5.2)$ & $7(12.1)$ & $11(18.9)$ & $17(29.3)$ & $17(29.3)$ \\
\hline $\begin{array}{l}\text { Specialized } \\
\text { Clinical } \\
\text { Competence }^{1} \\
\text { (Substance affected } \\
\text { LGBT consumers) } \\
(n=55)\end{array}$ & $\begin{array}{l}\text { Very } \\
\text { Important } \\
n(\%)\end{array}$ & $\begin{array}{l}\text { Somewhat } \\
\text { Important } \\
n(\%)\end{array}$ & $\begin{array}{l}\text { Neutral } \\
n(\%)\end{array}$ & $\begin{array}{l}\text { Not Important } \\
n(\%)\end{array}$ & $\begin{array}{l}\text { Not Very } \\
\text { Important } \\
n(\%)\end{array}$ \\
\hline LGBT & $31(53.4)$ & $12(20.7)$ & $7(12.1)$ & $2(3.4)$ & $3(5.2)$ \\
\hline
\end{tabular}

${ }^{1}$ Individual percentages calculated using all potential respondents $(N=58)$ 
Table 5: Service Providers: Affirming Identification \& Consumer Sociodemographics $(N=5)$

\begin{tabular}{|c|c|c|c|c|}
\hline $\begin{array}{l}\text { Identify as LGBT } \\
\text { Affirming }^{1} \\
(n=3)\end{array}$ & $\begin{array}{l}\text { Yes } \\
n(\%)\end{array}$ & $\begin{array}{l}N o \\
n(\%)\end{array}$ & & \\
\hline & $5(00)$ & $2(40)$ & & \\
\hline $\begin{array}{l}\text { Percentage of } \\
\text { LGBT Clients }^{1} \\
(n=5)\end{array}$ & $\begin{array}{l}0-25 \% \\
n(\%)\end{array}$ & $\begin{array}{l}26-50 \% \\
n(\%)\end{array}$ & $\begin{array}{l}51-75 \% \\
n(\%)\end{array}$ & $\begin{array}{l}76-100 \% \\
n(\%)\end{array}$ \\
\hline Lesbian & $5(100)$ & N/A & $\mathrm{N} / \mathrm{A}$ & $\mathrm{N} / \mathrm{A}$ \\
\hline Gay & $2(40)$ & $2(40)$ & $1(20)$ & $\mathrm{N} / \mathrm{A}$ \\
\hline Bisexual & $5(100)$ & N/A & $\mathrm{N} / \mathrm{A}$ & $\mathrm{N} / \mathrm{A}$ \\
\hline Transgender & $4(80)$ & $\mathrm{N} / \mathrm{A}$ & $\mathrm{N} / \mathrm{A}$ & $\mathrm{N} / \mathrm{A}$ \\
\hline $\begin{array}{l}\text { Racial/Ethnic } \\
\text { Composition of } \\
\text { Clients }^{1} \\
(n=5)\end{array}$ & $\begin{array}{l}0-25 \% \\
n(\%)\end{array}$ & $\begin{array}{l}26-50 \% \\
n(\%)\end{array}$ & $\begin{array}{l}51-75 \% \\
n(\%)\end{array}$ & $\begin{array}{l}76-100 \% \\
n(\%)\end{array}$ \\
\hline African American & $1(20)$ & $3(60)$ & $\mathrm{N} / \mathrm{A}$ & $\mathrm{N} / \mathrm{A}$ \\
\hline Caucasian & $1(20)$ & $1(20)$ & $2(40)$ & $1(20)$ \\
\hline Hispanic/Latino & $4(80)$ & $1(20)$ & $\mathrm{N} / \mathrm{A}$ & $\mathrm{N} / \mathrm{A}$ \\
\hline Asian & $5(100)$ & N/A & N/A & N/A \\
\hline Native American & $5(100)$ & N/A & $\mathrm{N} / \mathrm{A}$ & N/A \\
\hline Multiracial/Other & $4(80)$ & $1(20)$ & $\mathrm{N} / \mathrm{A}$ & $\mathrm{N} / \mathrm{A}$ \\
\hline $\begin{array}{l}\text { Gender } \\
\text { Composition of } \\
\text { Clients }^{1} \\
(n=3) \\
\end{array}$ & $\begin{array}{l}0-25 \% \\
n(\%)\end{array}$ & $\begin{array}{l}26-50 \% \\
n(\%)\end{array}$ & $\begin{array}{l}51-75 \% \\
n(\%)\end{array}$ & $\begin{array}{l}76-100 \% \\
n(\%)\end{array}$ \\
\hline Male & N/A & N/A & $4(80)$ & $1(20)$ \\
\hline Female & $1(20)$ & $4(80)$ & $\mathrm{N} / \mathrm{A}$ & $\mathrm{N} / \mathrm{A}$ \\
\hline Trans Male & $5(100)$ & N/A & $\mathrm{N} / \mathrm{A}$ & $\mathrm{N} / \mathrm{A}$ \\
\hline Trans Female & $5(100)$ & $\mathrm{N} / \mathrm{A}$ & $\mathrm{N} / \mathrm{A}$ & $\mathrm{N} / \mathrm{A}$ \\
\hline Other & $5(100)$ & $\mathrm{N} / \mathrm{A}$ & N/A & N/A \\
\hline
\end{tabular}

${ }^{1}$ Individual percentages calculated using all potential respondents $(N=5)$ 
Table 6: Service Providers: Commitment, Competence and Perceptions of Students/Alumni Preparedness to Serve LGBT Substance Affected Consumers $(N=5)$

\begin{tabular}{|c|c|c|c|}
\hline $\begin{array}{l}\text { Provider } \\
\text { Commitment } \\
(n=5)\end{array}$ & $\begin{array}{l}\text { Very } \\
\text { Committed } \\
n(\%)\end{array}$ & $\begin{array}{l}\text { Somewhat } \\
\text { Committed } \\
n(\%)\end{array}$ & \\
\hline LGB & $4(80)$ & $1(20)$ & \\
\hline Transgender & $4(80)$ & $1(20)$ & \\
\hline $\begin{array}{l}\text { Provider } \\
\text { Competence } \\
(n=5)\end{array}$ & $\begin{array}{l}\text { Very } \\
\text { Competent } \\
n(\%)\end{array}$ & $\begin{array}{l}\text { Somewhat } \\
\text { Competent } \\
n(\%)\end{array}$ & $\begin{array}{l}\text { Not } \\
\text { Competent } \\
n(\%)\end{array}$ \\
\hline Lesbian & $3(60)$ & $2(40)$ & N/A \\
\hline Gay & $3(60)$ & $2(40)$ & $\mathrm{N} / \mathrm{A}$ \\
\hline Bisexual & $3(60)$ & $2(40)$ & $\mathrm{N} / \mathrm{A}$ \\
\hline Transgender & $3(60)$ & $\mathrm{N} / \mathrm{A}$ & $1(20)$ \\
\hline \multirow[t]{2}{*}{$\begin{array}{l}\text { Interns and Staff } \\
\text { with Specialized } \\
\text { Training }^{1} \\
(n=5)\end{array}$} & $\begin{array}{l}\text { Somewhat } \\
\text { Important } \\
n(\%)\end{array}$ & $\begin{array}{l}\text { Very Important } \\
n(\%)\end{array}$ & \\
\hline & $2(40)$ & $3(60)$ & \\
\hline $\begin{array}{l}\text { Coursework } \\
\text { Preparedness }^{1} \\
(n=5)\end{array}$ & $\begin{array}{l}\text { Very Well } \\
n(\%)\end{array}$ & $\begin{array}{l}\text { Somewhat Well } \\
n(\%)\end{array}$ & $\begin{array}{l}\text { Do Not } \\
\text { Know } \\
n(\%) \\
\end{array}$ \\
\hline LGB & $2(40)$ & $2(40)$ & $1(20)$ \\
\hline Transgender & $2(40)$ & $1(20)$ & $2(40)$ \\
\hline $\begin{array}{l}\text { Field Placement } \\
\text { Preparedness }{ }^{1} \\
(n=5)\end{array}$ & $\begin{array}{l}\text { Very Well } \\
n(\%)\end{array}$ & $\begin{array}{l}\text { Somewhat Well } \\
n(\%)\end{array}$ & $\begin{array}{l}\text { Do Not } \\
\text { Know } \\
n(\%)\end{array}$ \\
\hline LGB & $2(40)$ & $2(40)$ & $1(20)$ \\
\hline Transgender & $2(40)$ & N/A & $2(40)$ \\
\hline $\begin{array}{l}\text { Student/Alumni } \\
\text { Competence }^{1} \\
(n=5)\end{array}$ & $\begin{array}{l}\text { Very } \\
\text { Competent } \\
n(\%)\end{array}$ & $\begin{array}{l}\text { Somewhat } \\
\text { Competent } \\
n(\%)\end{array}$ & $\begin{array}{l}\text { Do Not } \\
\text { Know } \\
n(\%)\end{array}$ \\
\hline Lesbian & $2(40)$ & $2(40)$ & $1(20)$ \\
\hline Gay & $2(40)$ & $2(40)$ & $1(20)$ \\
\hline Bisexual & $2(40)$ & $1(20)$ & $1(20)$ \\
\hline Transgender & $2(40)$ & $1(20)$ & $2(40)$ \\
\hline
\end{tabular}

${ }^{1}$ Individual percentages calculated using all potential respondents $(N=5)$ 